\title{
A Revolução Francesa e seu eco *
}

\section{Michel Vovelle}

Abordar o imenso canteiro de obras da Revolução Francesa, a partir do alcance do eco que ela encontrou na Europa e no mundo, é mais que se conformar com a vocação própria de um "Congresso Internacional das Luzes", atento por natureza à abordagem comparativa, assim como aos fenômenos de difusão: é também responder à solicitação de um momento. Estamos nos preparando para comemorar o Bicentenário da "Grande Revolução": um acontecimento que pertence tanto ao patrimônio da humanidade quanto ao da França; a tentação de um balanço impōe-se legitimamente. É nesta óptica que se prepara em Paris a realizaçāo, em 1989, de um Congresso Mundial sobre o tema da "Imagem da Revolução Francesa", para o qual o confronto atual sobre um tema semelhante, mas não idêntico, certamente contribuirá. Sob o termo imagem, proposto pelo professor Ernest Labrousse, entende-se, com efeito, o estudo de todas as formas de recepção no pensamento político, filosófico ou histórico, como na literatura, na arte e mais amplamente todos os suportes do imaginário, das idéias-forças, assim como da memória do acontecimento.

Falar aqui de eco (ou de repercussão) da Revolução parece, à primeira vista, limitar o campo operacional, ainda que os autores que responderam a essa solicitação tenham considerado o termo em toda a riqueza das leituras que ele autoriza, do que dá testemunho a multiplicidade dos equivalentes semânticos encontrados no decorrer das comunicaçōes (eco, ressonância, influência, difusão, recepção, impacto, repercussões, reações, legados, ou herança ...). Tal lista tendo sido evocada não apenas pela curiosidade, mas pelas nuanças que sugere na maneira de abordar o problema. Limitar-nos-emos à leitura mais imediata do termo como percepção, impressão causada pela Revolução Francesa sobre os contemporâneos, sem levar em conta os abalos profundos que provocou nos sistemas institucionais e sociais? Vários autores não hesitaram em transpor essa fronteira, e certamente com toda a razão. Um mesmo número de pesquisadores inscreveram deliberadamente sua reflexão na história do século XIX aos dias de hoje, considerando que o eco diferido ou prolongado é tão importante quanto o eco imediato. Tal conduta impõe-se sobremaneira, tanto que em muitos países, por razōes ao mesmo tempo geográficas e históricas, o impacto contemporâneo dos fatos foi modesto, até mesmo nulo; a descoberta ulterior, ao contrário, notável e duradoura em seus efeitos. Partilhamos de boa vontade desse ponto de vista, mesmo que pareça à primeira vista exceder os limites cronológicos de um encontro de setecentistas. É ao longo do tempo que se aprecia a dimensão real do acontecimento que encerra o Século das Luzes.

* Texto apresentado no "70 Congresso Internacional das Luzes", em Budapeste, no período de 26 de julho a 2 de agosto de 1987. Traduzido por Magda Sento Sé Fonseca. 


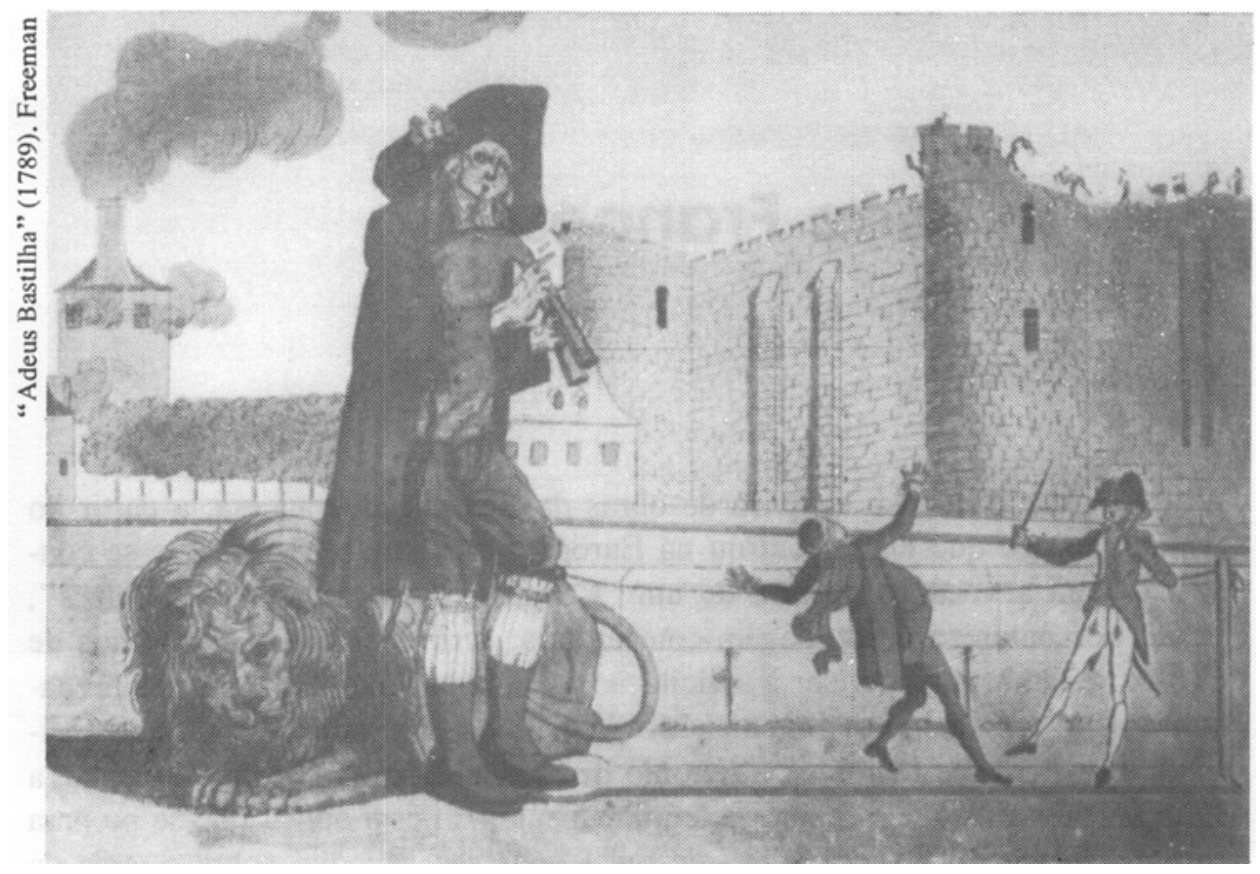

A bem dizer, a diversidade das contribuiçôes propostas deixa incontestavelmente a impressão de um canteiro amplamente aberto, tanto numa perspectiva geográfica quanto temática. Sendo, antes, em termos de problemas ou de programas de balanço, que convém apresentar esta exposição.

\section{Um Canteiro Antigo e Novo}

A afirmação pode parecer paradoxal: que se tenha falado em termos de conquistas da Liberdade, ou das vitórias da Grande Nação, ou, ao contrário, de denúncia do contágio revolucionário, o problema do eco da Revolução é tão velho quanto o próprio acontecimento. De início, num gigantesco diálogo com múltiplas vozes, onde Burke e Thomas Paine se respondem, onde Chateaubriand e Joseph de Maistre se esforçam para teorizar a quente a experiência em curso e dar-lhe resposta, o problema da Revolução foi colocado em termos gerais. Mas, como pode ter sido de outra forma, se o confronto armado, a partir de 1792, e até 1815, conduzia a um abalo generalizado da Europa monárquica em seus equilíbrios mais enraizados?

Passar dessas reaçōes a quente às abordagens científicas do tema, demandaria um percurso historiográfico em cujo detalhe não entraremos. Nas grandes obras históricas da época romântica, de Thiers a Michelet, a Lamartine ou a Louis Blanc, a dimensão internacional do abalo revolucionário está longe de estar ausente, mas continua, no estado dos conhecimentos, galocêntrica, apesar de virem do exterior consideraçōes que ainda se hipnotizam com o acontecimento da Revolução em si, como Carlyle, que trata desse "prodígio chamado Revoluçāo Francesa que o Universo ainda olha com estupefação". Logo, testemunho - e de que amplitude - sobre o eco da Revolução, mais que estudo do fenômeno. Por certo uma virada se esboça nas origens de uma história positivista, que se encontra com a afirmação das nacionalidades, assim como acontece em von Sybel, cuja Geschichte der Revolutionszeit, redigida entre 1853 e 
'858, é truảuida em francês com o título A Europa e a Revolução Francesa (1869-1887): mas a liberdade tomada com o título original não afirma umi àeslize significativo do tema? Também na França caminhava por vias comparàveis, pois se Taine, em suas Origens da França Contemporânea, não focaliza particularmente a questão, pode-se dizer que ele a transmitiu a um de seus aiscípulos, Albert Sorel, cujos oito tomos de A Europa e a Revolução escalonam-sr entre 1874 e 1904. Mesmo se Sorel não compartilha de todas as opiniōes de Taine, ele representa bem a atitude da França conservadora e nacionalista, interessada em fazer surgir da continuidade de uma herança histórica, mais que da ruptura revolucionária, esta novidade incontornável, como se diz hoje, que é a nação do tipo moderno: um conceito que a França revela à Europa às suas custas.

Definitivamente, esse monumento traz o peso de sua idade, quando voltamos a visita-lo hoje, restringindo o cncadeamento dos fatos a uma estreitíssima visão de história diplomática. Que contraste com o tomo - menos erudito, por certo, mas de que inspiraçáo! - em que Jean Jaurès consagra então a "A Revolução e a Europa", como quarta seqüência de sua História Socialista, rompendo a continuidade cronológica do percurso para abordar o problema em toda sua densidade, dando às condições sócio-econômicas dos parceiros europeus a parte que lhes cabe, formando o retrato dos jacobinos alemães ou ingleses, evocando as condiçōes de seu difícil combàie, dando a maior atenção, principalmente aos pensadores, dos mais modestos aos mais eminentes, dos difusores da Revolução, como Fichte e seus maiores adversários, Burke em primeiro lugar. Certamente este panorama também exploratório confessa seus limites: é parcial e descontínuo. Se reserva um lugar para as revoluçóes da Suíça, coloca, na verdade, toda a ênfase sobre o mundo germânico de um lado, sobre a Inglaterra de outro. Ignora a Itália de que Jaurès fala muito brevemente (no tomo precedente), e a Espanha, o que é mais facilmente desculpável. A Europa Central e Oriental não encontra lugar no desenvolvimento do tomo IV. Nessa seleção refletem-se ao mesmo tempo a cultura de Jaurès, com seus pontos de ancoragem e seu sistema de referência, mas também as vastas zonas de sombra na bibliografia e conhecimentos de seu tempo. Em função disso, pode-se também apreciar um testemunho sobre uma etapa da descoberta.

Pois os canteiros, na França e mais ainda no resto do mundo, multiplicaram-se no século XX. É interessante acompanhar-lhe ao mesmo tempo a geografia e a respiração global, a partir dos instrumentos bibliográficos, ou mais simplesmente, bibliografias de algumas obras de referência como a que propu-

A afirmação pode parecer paradoxal: que se tenha falado em termos de conquistas da Liberdade, ou das vitórias da Grande

Nação, ou, ao contrário, de denúncia do contágio revolucionário, o problema do eco da Revolução é tão velho quanto o próprio acontecimento. nha A. Sorel em anexo ao tomo IV de Jaurès em sua reedição de 1971, mas melhor ainda as que acompanharam em 1958, depois em 1983, as duas ediçōes da obra essencial de Jacques Godechot, A Grande Nação. Além disso, o mesmo Jacques Godechot escreve periodicamente na Revue Historique (francesa) uma crônica atenta aos aparecimentos de publicaçōes internacionais a que se pode referir. $\mathrm{E}$ também $\mathrm{o}$ anúncio das iniciativas internacionais (e algumas vezes francesas) suscitadas pela aproximação do Bicentenário, assim como colóquios e publicações que as acompanham, como a que expressamos recentemente nos diferentes boletins da Comissão de Pesquisa Histórica pelo Bicentenário da Revolução Francesa (CNRS, França), autoriza um baianço não apenas muito atual, mas prospectivo. 
Dessas confrontaçōes, um certo número de linhas de força se destacam. Notar-se-ão, desde o início do século, tempos fortes e tempos fracos: um vivo interesse nos trinta primeiros anos, da França à Alemanha, um branco relativo, dos anos $\mathbf{3 0}$ ao fim da Guerra nos países atingidos pelos fascismos, um certo despertar nos anos 50, quando a problemática das "Revoluções Atlânticas", apresentada em 1955 ao Congresso de Roma, funcionou ao mesmo tempo como um elemento de relançamento para uma leitura comparativa dos fenômenos revolucionários que conduz à apreciaçāo de suas influências comparadas, e mais ainda, talvez como testemunho de um interesse múltiplo. É ao longo dos anos 50 que as grandes sínteses são publicadas, quase paralelamente:

Jacques Godechot, A Grande Nação (1956, retomada, como vimos, em 1983);

Robert Palmer, The Age of the democratic revolution (1959-1964);

Eric Hobsbawn, The Age of revolutions (1962)...

Trabalhos ambiciosos e meritórios, cujo duradouro sucesso ressalta-lhes a importância, mas que marcam uma época, já que não foram atualizados. Desde então, se é devido destacar com pesar o retrocesso relativo da produção francesa, onde o revezamento nāo parece assegurado no campo da história das revoluçōes desde a geraçāo de Godechot, J. Droz ou J. R. Suratteau, convém frisar a notável explosão das histórias nacionais dedicadas ao período.

Os historiadores americanos que se seguiram a Palmer interessaram-se não apenas por sua própria revolução e sua influência, mas pelos canteiros do velho continente. A historiografia germânica é prova de um notável dinamismo nas duas Alemanhas como numa Áustria que, dos trabalhos de W. Grab aos de H. Reinalter, valoriza sua posição no coração da Mitteleuropa. Se deve ser frisada na Europa "Atlântica" a vitalidade de uma historiografia inglesa, que se inclina sobre seus jacobinos, mas não se digna a olhar alhures, e a afirmação de uma historiografia neerlandesa e belga (colóquio sobre a Revoluçāo brabançona 1982), como de uma escola helvética alimentando-se da boa tradição, os traços mais espetaculares, no entanto, aparecem, sem dúvida, durante a produção italiana, como a afirmação das escolas da Europa Central ou Oriental. Na estatística proposta em 1979 para os anos 70, em sua crônica da Revue Historique, Jacques Godechot, sob a rubrica global "expansão revolucionária fora da França", recenseava um número de 43 títulos, 20 obras sobre a Itália, muito na frente da área germânica (5 títulos) ou da americana (4 títulos): teste de um prestígio que não tem coisa alguma de passageiro, desde os anos 50. Na Polônia, como na Hungria, toda uma série de estudos fundamentais sucederam-se desde os trabalhos pioneiros dos anos 50 sobre os jacobinos, de Lesnodorski ou de Benda: os historiadores franceses tiveram conhecimento deles a partir de números especiais dos Anais Históricos da Revolução Francesa. São setores em pleno despertar os da Europa Central ou Balcânica (Tchecoslováquia, Romênia, Bulgária, Grécia...). Mas deve-se, também, passando pela península Ibérica, onde a atenção dada ao período por ser recente é mais viva, ressaltar o aparecimento de novas frentes pioneiras na América Latina, do Brasil à área caraíba. Livre de suas conotaçōes inutilmente polêmicas, e talvez de seu caráter demasiadamente sistemático, esteja talvez o sucesso diferido de uma "Revolução Atlântica", reduzida à sã incitação para uma abordagem comparativa.

Explosāo no espaço, explosāo também no tempo; uma parte importante desses estudos inscreveram-se no quadro mais amplo de uma visão renovada
Mas hoje as novas abordagens - as das palavras-chave, e mesmo pelas idéias-força, a partir da análise do discurso, as dos diferentes suportes do imaginário coletivo - abrem novas perspectivas a essas confrontações. Novas fontes foram valorizadas, da imprensa à imagem. 
das Luzes européias e dos estudos de sua difusão, ou de sua influência, que deram lugar a toda uma série de encontros, de historiadores ou de literatos. Assim o problema das origens, ou das raízes, ocupa posição privilegiada tanto no nível da influência dos grandes pensadores quanto no das aberturas de caminho (sociabilidade maçônica, edição) que operam no período pré-revolucionário. A jusante, são os ecos de longo prazo da Revolução Francesa que solicitam as pesquisas, como é o caso nos países da Europa Central, Balcânica e do Leste, onde a difusão dessa imagem se operou no decurso dos movimentos nacionais $e$ revolucionários do século XIX. Mas a questão se coloca em termos semelhantes para a América Latina.

Mais globalmente, é a própria concepçāo desse tipo de estudo que se modificou profundamente, como reflexo do enriquecimento dos territórios da pesquisa. Estamos bem longe da história européia contada no nível das chancelarias e no das embaixadas por Albert Sorel. $O$ aspecto pluridisciplinar da pesquisa, por não ser total novidade, afirmou-se. A história literária comparada, como a história das idéias, nāo ignora o campo dé pesquisa que oferece a seqüência revolucionária. Mas hoje as novas abordagens - as das palavras-chave, e mesmo pelas idéias-força, a partir da análise do discurso, as dos diferentes suportes do imaginário coletivo - abrem novas perspectivas a essas confrontaçōes. Novas fontes foram valorizadas, da imprensa à imagem. Sem aventurar-se em estabelecer um balanço que seria necessariamente prematuro, pode-se arriscar uma definição dos canteiros desse levantamento sobre o eco da Revoluçāo. Por comodidade pedagógica, aborda-los-ei em dois níveis: o eco imediato dos acontecimentos da França, se não os da década revolucionária estreitamente definida, ao menos durante o ciclo 1789-1815 que corresponde a uma periodização amplamente adotada pelos autores europeus ou outros, na medida em que o período imperial prolonga e exporta uma importante parte das conquistas revolucionárias. Depois, o eco diferido, ou se preferir, a Revolução após a Revolução, outro efeito do eco que se vê elaborando uma imagem na memória coletiva.

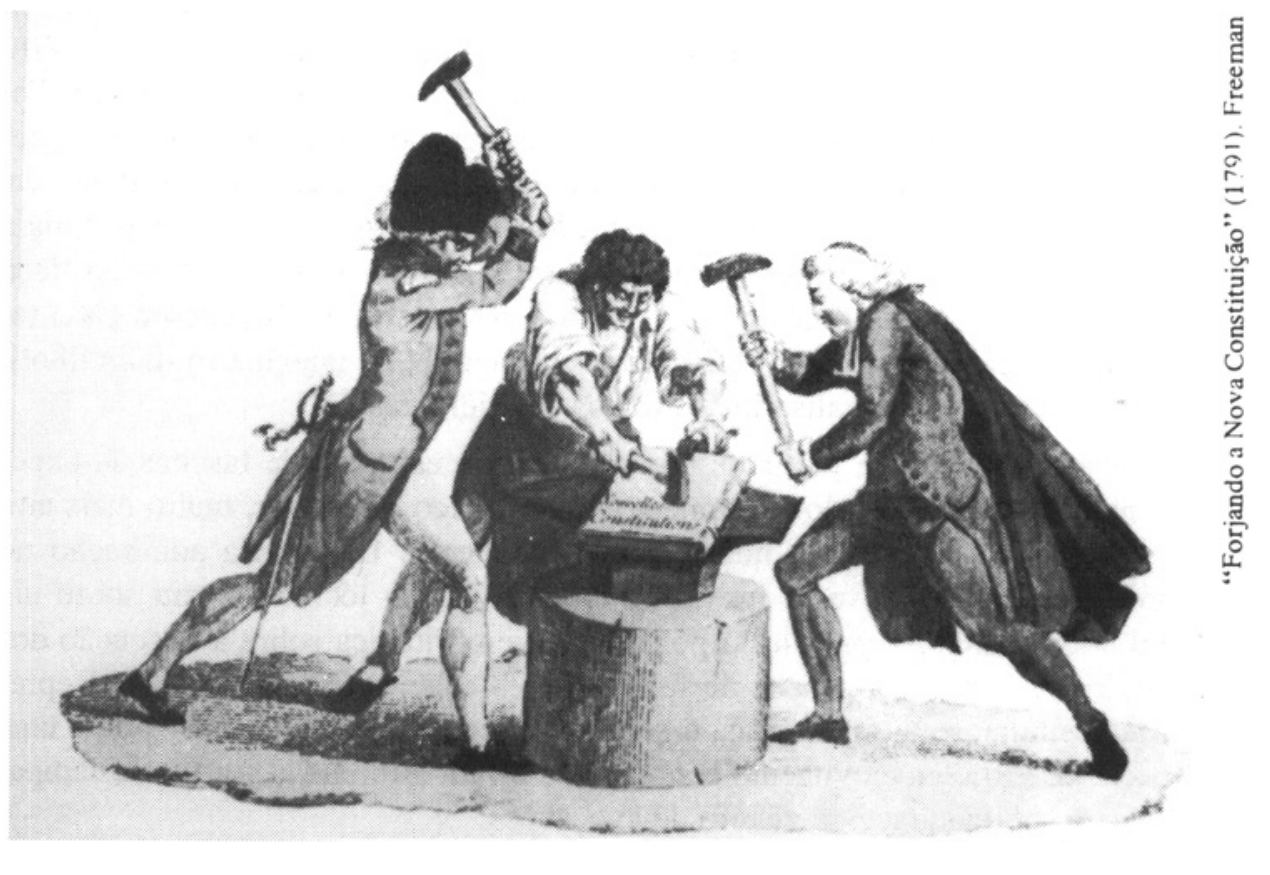


O eco imediato: 0 impacto da Revolução sob a Revolução.

Tal investigação inicia-se num nível modesto, ou factual: como a Revolução ficou conhecida, em que meios, em que limites e em que termos? O levantamento há pouco lançado por Jacques Godechot, a partir de um teste preciso do conhecimento e difusāo da declaração dos Direitos do Homem nos diferentes países europeus, recebeu elementos de resposta da Inglaterra, da Alemanha ou da Itália. Outras contribuições continuam a enriquecê-lo, como a recente, de Godwin, sobre a recepção da declaraçāo dos direitos nos Países Baixos, lugar interessante ao mesmo tempo porque o clima de reação que então reina faz termos à medida dos obstáculos encontrados, mas, por outro lado, a tradição jornalística neerlandesa garante uma difusão precoce se não integral.

A partir de outros suportes, ou de outros acontecimentos recuperados, escalonados durante a Revolução, conviria precisar este estudo de ondas de difusão, assim como para a Bastilha (não se pode ficar eternamente aprisionado na imagem, simbólica, é verdade, da caminhada diária de Immanuel Kant em Königsberg, perturbada por esse anúncio). Sem multiplicar os exemplos, pode-se imaginar um acontecimento como a morte do rei em 21 de janeiro de 1793, que teve na sensibilidade e na opinião européia um eco imenso, e, para dizer a verdade, bem mantido por toda uma corrente de propaganda. Pode-se supó-lo a partir de certos suportes privilegiados, como a imagem ou a numismática. Os artistas europeus que abundantemente produziram sobre o tema responderam por certo parcialmente a uma pergunta social, como se diz hoje, onde os meios de emigração francesa tiveram sua parte, mas igualmente num mercado local, nos grupos nobiliários ou burgueses. Como havia ocorrido, um século e meio antes, uma reação européia, da França à Alemanha barroca, por ocasião da morte de Carlos I, a opiniâo focaliza também sua atenção sobre a morte e paixão de Luís XVI: artistas franceses emigrados a Londres, artistas ingleses ou internacionais fixam sobre suas séries gravadas as etapas das desventuras não apenas do rei mas de sua familia, de Maria Antonieta e Madame Elisabete. A numismática, fazendo-nos descobrir, juntamente com as cuidadas séries alemãs ou britânicas, sobre o tema dos últimos adeuses de Luís XVI, moedas ou token ingleses de fabricação muito nústica, permite apreciarmos até que nível de difusão popular o tema de propaganda foi levado. Se acontecimentos como a Tomada da Bastilha ou a morte do rei impöem-se sem surpresa como provas de referência, pode-se também interrogar sobre a particular atenção depositada em certos personagens, e em certos traços: pode-se imaginar, por exemplo, toda a cristalização que se opera em torno do casal maldito - se me perdoam o traço de humor negro - Marat-Charlotte Corday, e não apenas na Inglaterra. Uma recente exposiçāo (Florença, 1986/87) foi consagrada ao imaginário da guilhotina, da qual uma obra analisa-lhe os traços (Daniel Arasse).

Pode-se seguir, a partir de tais referências, este tipo de fascinação experimentada na Europa pelo instrumento emblemático do Terror, muito mais ambíguo do que se acreditou num primeiro momento. Uma certa admiração no mundo germânico por uma inovação cuja realização técnica recaia sobre um hábil artesão alemão, partilhada por tal imagem britânica sobre a execução dos girondinos, sensível à proeza de fazer cair 28 cabeças em 35 minutos! Representaçōes totalmente fantásticas, e sem qualquer relação com a realidade - uma espécie de serra em movimento contínuo - , foram difundidas por uma estamparia alemã habituada a esse gênero de evocaçōes.
Pode-se seguir, a partir de tais referências, este tipo de fascinaçāo experimentada na Europa pelo instrumento emblemático do Terror, muito mais ambiguo do que se acreditou num primeiro momento. 


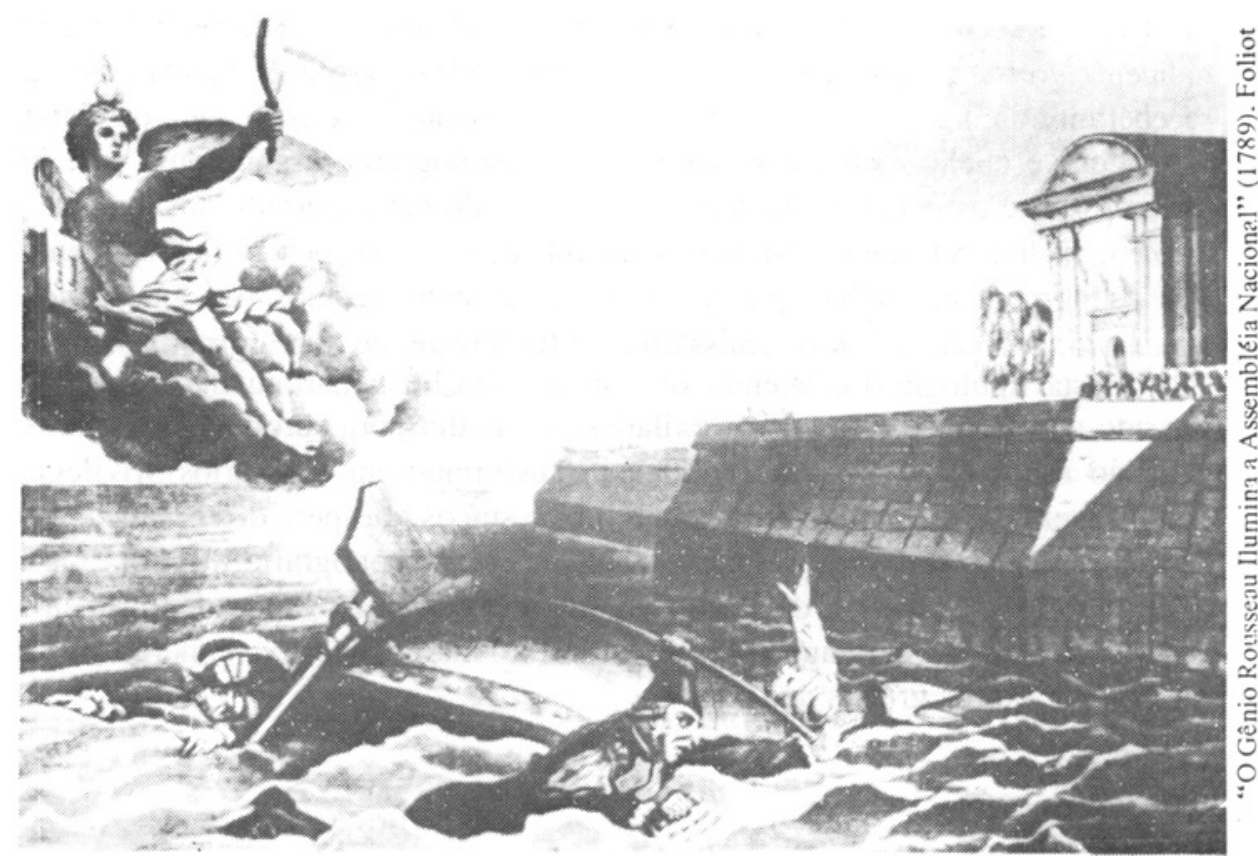

Deixemos esse tema macabro: ele tem ao menos o mérito de introduzirnos muito concretamente no problema da difusão das idéias-força, palavraschave, personagens emblemáticos, símbolos, a partir dos quais a Revolução Francesa se impôs quase imediatamente no imaginário europeu. Diversas questões se colocam: a dos agentes da propagação, a dos suportes, a dos próprios conteúdos que foram recebidos com simpatia ou rejeição violenta.

$\mathrm{Na}$ classe dos atores, é legítimo distinguir os que foram portadores ou difusores ativos das novidades revolucionárias - viajantes ou peregrinos da $\mathrm{Li}$ berdade, emigrados franceses, diplomatas, soldados ou missionários armados dos que receberam, difundiram e retransmitiram a mensagem no proprio lugar. Ficando bem entendido que de um a outro grupo existem passarelas estreitas e áreas de superposição recobertas: viajantes ou peregrinos da Liberdade tornaram-se várias vezes os prosélitos das idéias revolucionárias - ou seus adversários!

Pode-se ter o sentimento, recapitulando esses temas, de canteiros bem balizados: memórias e narrativas de viagens, principalmente nos primeiros tempos da Revolução, multiplicaram-se, e muitas dentre elas foram objeto de publicações completas ou por fragmentos. Esboça-se uma tipologia, onde o viajante do tipo clássico, tal como Arthur Young, que se encontra como testemunha dos primeiros episódios, se vê substituído pelos observadores - agentes diplomáticos ou consulares - ou patriotas exilados na França, por descobridores atraídos pela própria experiência da Revolução parisiense. Tais documentos foram muitas vezes explorados no nível factual dos detalhes ou dos episódios inéditos que podiam informar. Sonha-se com um tratamento global daquilo que se constitui hoje num verdadeiro corpus para analisar as visōes diferentes e as experiências dessas testemunhas vindas de outros lugares. Desde já, uma geografia de procedências esboça-se, onde os alemäes ocupam lugar de destaque, seguidos pelos britânicos. Dentro de uma perspectiva complementar, se o grupo dos emigrados franceses foi objeto de estudos parcialmente atualizados, principalmente 
no nível da sociologia como no das condiçōes de acolhimento, foram tradicionalmente considerados, desde a clássica obra de Baldensperger, mais pelo que receberam no contato com os países que descobriram, que pelo que veicularam - imagens e clichês sobre a Revolução. Tal monografia, assim como a de Picheloup sobre os poderes franceses nos estados do papa, permite-nos nuançar o quadro. Padres refratários, muitas vezes olhados com suspeiçấo nos conventos que os abrigavam, podem paradoxalmente, quando tratados por giacobino $e$ sanculoto, aparecer como os emissários da Revolução de que fugiram.

Nesta tipologia dos agentes de contato, um lugar particular deve ser reservado aos grupos dos patriotas exilados, a esta diáspora européia, cujo vai- evem, ao sabor das flutuações políicas, transformou em emissários privilegiados. Liegenses, belgas, batavos, ginebrinos e suíços, à espera dos renanos, e os italianos, são grupos inegavelmente conhecidos. A monografia que foi consagrada ao clube helvético de Paris e a sua ação de propaganda nos primeiros anos da Revolução permanece sob esse aspecto muito sugestiva e mereceria ser imitada por outros grupos nacionais.

\section{Mege Mory Stotes dat?}


Passemos - um tanto bruscamente talvez - a esta outra população dos que nos diversos países acolheram ou receberam o eco da Revolução, com o risco de repudiá-la em seguida. De maneira legítima, a atenção se concentrou tradicionalmente sobre os intelectuais, parceiros privilegiados - Kant, Fichte... e alguns outros. Essa óptica era a de Jaurès, fazendo da Revolução o ponto de chegada e a fermata das Luzes, e dava em troca à Revolução Francesa a garantia ao menos de uma parte dos grandes nomes do pensamento europeu. Esse canteiro do impacto ideológico da Revolução está muito longe, qualquer que seja a riqueza dos estudos que tenha suscitado, de ter esgotado suas virtualidades. A atenção se concentra naturalmente num certo número de exegetas que, num campo ou no outro, propuseram no próprio momento um modelo explicativo dos acontecimentos em curso: e compreende-se sem dificuldade o duradouro interesse conferido a Burke e às suas Consideraçōes sobre a Revolução Francesa. Por outro lado, interrogamo-nos igualmente sobre a continuidade de um intercâmbio mantido durante os acontecimentos entre pensadores ou teóricos franceses e seus colegas europeus. Os recentes estudos sobre Siéyès e sobre sua influência na Alemanha inscrevem-se dentro desta linha. Um dos problemas continua existindo: o da difusão - junto do qual, a que profundidade - dos best sellers em torno de que se focalizou o debate, a favor ou contra a Revolução. Se a influência de Burke é facilmente detectável, através de suas múltiplas traduçōes, como do lugar que ocupa na literatura contra-revolucionária, é mais difícil repertoriar em que fontes se alimenta a bibliografia dos jacobinos húngaros, poloneses ou mesmo alemães. A tarefa, no entanto, não é impossível, consistindo em discernir influências e referências, em saber também o que persegue a censura. Os jacobinos da Europa Central, que nos descreve H. Reinalter, têm conhecimento das proclamações essenciais da Revolução, leram o bom senso de Thomas Paine, uma espécie de antídoto contra as considerações de Burke.

Essa consideração conduz à tentativa de apreciação, por detrás das personalidades de primeiro plano, do retrato de grupo dos que se fizeram os campeōes e os artesãos da propaganda revolucionária e que se designou, por isso, o título coletivo de jacobinos, a convite dos próprios animadores da cruzada contra-revolucionária, Catarina II, a primeira. Este estudo é certamente um dos que foram mais amplamente renovados, em conseqüência do desenvolvimento de todas as historiografias nacionais evocadas acima.

Não queremos, absolutamente, propor aqui uma visão de conjunto dos jacobinos, ponta de lança da penetração da influência revolucionária na Europa. O que se pode dizer, em nível de simples apanhado, é que a acolhida dada à Revolução Francesa e a formação de grupos ativos, que partilhavam suas idéias, obtêm um primeiro impulso a partir de 1789, mas principalmente entre 1790 e 1792, particularmente encorajadas em 92 pela política de expansão revolucionária. É a época das curiosidades, dos entusiasmos, dos clubes também.

Passemos - um tanto bruscamente talvez - a esta outra população dos que nos diversos países acolheram ou receberam o eco da Revolução, com o risco de repudiá-la em seguida.
À primeira geração de jacobinos, no sentido algumas vezes muito vago, sucederá em 93, e principalmente em 94, uma outra plêiade, mais motivada, mais engajada e por vezes investida, pela marcha da história, das responsabilidades da ação: jacobinos de luta, ou de conspiraçōes, algumas vezes tidos falsamente, sobretudo no Diretório, como ligados a um sistema que a Revolução burguesa rejeitou e de que ela desconfia. 
Neste caso. tratamos apenas de cronologias nacionais, mas mesmo levando em conta as diferentes evoluções, a nebulosa dos jacobinos europeus se desenha em traços contrastados: na Europa Ocidental, os jacobinos ingleses agrupados em torno de Thomas Hardy na "Sociedade Correspondente de Londres" serāo perseguidos em 1794; noutras partes, o jacobinismo flamengo foi, após a experiência do levante de 1792 , muito brando, de recrutamento limitado, em contraste com a importância dos jacobinos batavos na Holanda vizinha. A atividade e o número dos clubes nesse país podem ser comparados com o que se passa na Suíça, onde os grupos que partilham das idéias francesas desenvolvem-se com base numa situação explosiva e pré-revolucionária em certas regiōes (Vauds, Valais): em novembro de 1794, as autoridades de Zurique detêm em Staia um grupo de conjurados jacobinos.

Jacobinismo de clubes na Alemanha, clubes igualmente, mas também organizaçōes revolucionárias (Buonarotti) na Itália, principalmente Setentrional, mas mais amplamente as grandes cidades (Milão, Nápoles, Bolonha, mesmo Roma), o mapa do jacobinismo europeu deixa de lado a Espanha, onde a idéia ainda atinge apenas alguns pontos isolados, como a Europa Oriental até alguns grupos próximos: começam a ser conhecidos os jacobinos poloneses (mesmo se a expressão de jacobinière de Catarina II é indiscutivelmente abusiva) como a história guardou a lembrança da conspiração dita de Martinovits o líder (o delator) do grupo dos jacobinos húngaros, executados em julho de 1794.

Quem foram os jacobinos europeus? Suspeitamos que não haja resposta simples a tal questão. Nos países onde a estrutura social era mais próxima da França (Bélgica, Países Baixos, Renânia, Suíça, Itália Setentrional) um recrutamento de domínio burguês tem um lugar importante junto aos intelectuais, por vezes aos nobres (Itália), mas pode abrir-se a elementos do artesanato e do comércio em meio urbano. Talvez seja aí que o retrato do jacobino difere menos radicalmente do jacobino francês do ano II; é aí também que a densidade dos clubes urbanos é a mais forte (Renânia, Holanda, Suíça, Itália Setentrional). Mas, o jacobinismo guarda um caráter minoritário e se choca com fortes resistências populares, em meio rural e mesmo urbano.

Em função de estruturas sociais diferentes, os jacobinismos se recrutam distintamente em outros lugares. Os que foram estudados no reino de Nápoles (Cingari), por ocasiāo do confronto entre giacobini $e$ San Fedisti, associam a alguns nobres um núcleo de burgueses urbanos; a contra-revolução sanfedista valorizará o caráter de luta cidade-campo do conflito, por ocasião de pilhagens onde aquele que tinha pão e vinho era considerado jacobino.

Quando ganham a Europa Central, o círculo se fecha mais claramente ainda em grupos de intelectusis (professores e funcionários públicos), a ausência da burguesia faz com que seja ali que por vezes se recrutem os jacobinos na pequena e pobre nobreza, o que ocorre com alguma ambigüidade, assim os jacobinos húngaros associam um grupo de intelectuais plebeus a um complô da nobreza (medíocre) reformista e crispada na defesa das liberdades húngaras; tendo aqueles certamente sonhado em aproveitar-se de um levante nobiliário para ultrapassar-lhe os objetivos. Entretanto, dentre os condenados de julho de 1794 na Hungria, há aproximadamente metade de pequenos nobres, para uma outra metade de intelectuais e funcionários públicos plebeus. Tal tipo aproximado de recrutamento se encontra no que se sabe dos jacobinos poloneses.
Quem foram os jacobinos europeus? Suspeitamos que năo haja resposta simples tal questão. 
A ideologia dos jacobinos europeus reflete ao mesmo tempo esse recrutamento diferente, em sua heterogeneidade, como em seus traços originais, apesar de uma dependência muitas vezes acentuada com respeito à fonte francesa dos escritos e dos exemplos a serem seguidos. Seria injusto dizê-la mais moderada ou reformista que a do jacobinismo francês. Ao contrário, a própria situação minoritária dos jacobinos muitas vezes tomou mais vivos certos engajamentos; assim a dimensão de contestação social alimentada na fonte babuvista foi nítida tanto na Holanda como na Itália (Buonarotti). Por outro lado, principalmente na Itália, o anticlericalismo pronunciado é um dos traços marcantes do jacobinismo. Uma historiografia tradicional apoiou-se por vezes em certos traços de verbalismo gratuito e exagerado (como para os clubes da Italia do Norte), talvez o problema devesse ser reestudado. De qualquer forma, quer parecer que a etiqueta, menos precisa que na França, de jacobino, tenha recoberto na Europa engajamentos mais diversificados, indo de um reformismo pouco fervoroso, na 
tradição das Luzes, a um engajamento extremado. Uma outra característica desses jacobinismos é o destaque dado ao problema nacional ou patriótico: presume-se que tenha sido formulado em termos diferentes segundo se trate de nacionalidades constituídas ou em vias de formação, ou em situação de dependência; diferentes igualmente uma vez que a conquista francesa colocou os jacobinos algumas vezes em situação ambígua de amigos de um libertador, passando muitas vezes a opressor. Evidente na Polônia ou na Hungria, se não sem equívoco (os dois níveis de iniciação dos jacobinos húngaros), este elo situa o jacobinismo nas origens do movimento nacional do século XIX. Dá-se o mesmo, mas segundo modalidades diferentes, na Itália, Alemanha, Sứça, Bélgica, Holanda, onde as próprias condições da expansão francesa impõem aos jacobinos locais uma marcha mais complexa.

Enfim, pode-se resumir em algumas palavras os traços que parecem caracterizar as formas da ação jacobina na Europa durante a Revoluçāo Francesa. Inicialmente, não é ação violenta, mas sim proselitismo apoiado nos clubes, como na França, com a diferença, é claro, que a densidade foi muito desigual: nuìneroso na Bélgica, na Holanda, numa parte da Suíça (até 50 em Genebra!), na Itália Setentrional e na Renânia. Em outros lugares, o clube tornou-se sociedade de pensamento ou de leitura, oficial ou clandestina de acordo com o momento. A imprensa e as sociedades de pensamento foram, algumas vezes, as maiores manifestações do jacobinismo que monografias atuais permitem-nos apreciar-lhes a importância (como na Alemanha do Norte para clubes como Altona ou Lübeck). Noutros lugares, os jacobinos locais achavam-se sempre em atraso, senão de uma guerra, ao menos de uma meia-revolução. Entendamos que após um período de luta e de clandestinidade, conduzindo muitas vezes ao exílio (lembremos a importância do mundo cosmopolita dos exilados em Paris entre 1792 e 1794), encontravam-se ora levados praticamente a colocar-se a serviço da ocupação francesa, ora perseguidos ou obrigados durante o Diret6rio, Consulado e o Império, a permanecer ou entrar numa semiclandestinidade. Esta posiçāo explica que os jacobinismos, mesmo europeus, tenham sido freqüentemente conspiradores, isso tanto para a Itália como também, a fortiori, para a Europa Central.

Nesta abordagem por círculos concêntricos dos meios atingidos pelo impacto da Revolução, mesmo com o risco de uma substituição dos intelectuais, que atraem primeiramente o olhar, pelo grupo (ainda uma elite) dos jacobinos, continua muito difícil apreciar as outras formas de acolhida ou de percepção na opiniāo, singularmente nos grupos populares ou na pequena burguesia, onde ela é desenvolvida. Levando a ingenuidade ao extremo, pode-se perguntar: o que conheceram os camponeses russos da grande revolução que se operara no outro extremo da Europa, antes da intrusão devastadora do Grande Exército em 1812? Mas a questão pode ser colocada, em termos diferentes, na Polônia, Hungria, etc. E qual imagem da revolução podiam ter os camponeses do Mezzogiorno, sanfedistas ou Viva Maria em 1798, senão fantástica? Aqui a dificuldade é duppla, tratando-se de grupos silenciosos onde a investigação é por definição incômoda, mas liga-se também à extrema diversidade das tomadas de contato com o fato revolucionário, de um extremo a outro da Europa. Podem ser distinguidos, em diferentes momentos, focos revolucionários onde, seguidamente ou não aos movimentos populares dos anos 80 , abrem caminho flame-
A imprensa e as sociedades de pensamento foram, algumas vezes, as maiores manifestaçōes do jacobinismo que monografias atuais permitem-nos apreciar-lhes a importância. 
jantes, insurreiçōes que testemunham o eco da Revolução Francesa. Do país de Liège à Renânia, a Genebra e ao país de Vaud e a Valais, mas também a Saxe, a Piemont e à Polônia é claro, e ainda nos anos 93-94 aos territórios Habsbourg, da Áustria à Boêmia ou à Hungria, de acordo com diferentes graus de mobilização ou de tomada de consciência, manifestam-se as repercussōes do fato revolucionário.

Como a propaganda revolucionária penetrou nesses diferentes meios? Evidentemente, as vias de penetração são muito diferentes, conforme os países tenham sido atingidos diretamente pela penetração revolucionária e a expansão francesa, ou pertencessem à Europa dos príncipes que se protegiam contra ela.

Entretanto, um certo número de suportes comuns se apresentam: clubes, sociedades ou lojas de um lado, difusão por escrito, a imprensa e a imagem de outro, e enfim, mas unicamente onde a revolução se implanta, cenografias da festa e pedagogias diversas.

Falando dos grupos jacobinos, já fomos levados a ressaltar a importância dos clubes como elementos estruturantes da influência revolucionária. $\mathbf{O}$ estudo da rede dessas organizações foi conduzido parcialmente; pôde-se propor uma categoria dos clubes renanos, em torno de Mayence em 1792, como se conhece a semeadura muito densa dessas organizaçōes, tanto na Holanda como numa parte da Suíça. Entre 1796 e 1799, estuda-se a rede das sociedades italiánas sob suas diversas denominaçōes - e pode-se esboçar sua trama, desigualmente densa do norte ao sul da península. Uma documentação por vezes excepcionalmente rica, como o fundo do círculo constitucional de Bolonha, muito recentemente publicado, permite melhor conhecer, do interior, o funcionamento desses organismos. A abordagem monográfica sobre este canteiro ainda novo não deu sua última palavra. Da mesma forma, apesar dos inúmeros e precisos estudos que foram realizados sobre os jacobinos vienenses e húngaros, através da conspiração de Martinovits, calcula-se a amplitude da pesquisa a ser processada, passando por Praga, Innsbruck e outros lugares para avaliar a função das lojas maçônicas e das sociedades secretas nos estados dos Habsbourg.

A função da imprensa na difusão das notícias e dos reflexos da Revolução não foi desprezada. Favorável ou hostil, muito depressa em liberdade estreitamente vigiada, ela ecoou os acontecimentos da França nas zonas anexadas - da Bélgica ao Reno, como mais tarde nas repúblicas irmãs - , foi o coração do dispositivo pedagógico da Revolução conquistadora. É, de fato, todo um dispositivo articulado que progressivamente se instaura, associando propaganda direta e indireta. A título de exemplo, uma instituição como a imprensa dos exércitos em Bruxelas mereceria ser reestudada em suas diferentes formas de atividade. Também nesse campo, fora das zonas que entram diretamente na órbita de influência francesa, uma frente de pesquisas desenha-se no nível de uma pequena literatura de difusão semipopular cujos almanaques são muito representativos. Os almanaques alemães, algumas vezes com um fundo de simpatia inicial pela tradiçāo das Luzes, muitas vezes transformaram-se em instrumentos de propaganda contra-revolucinaria, difundindo e talhando os clichês anti-franceses.

E que terreno de predileção para nosso estudo é a imagem sob todas as suas formas! Suas riquezas começam apenas a ser descobertas: iconografia prorevolucionária, francesa ou estrangeira, iconografia contra-revolucionária, in- 
glesa, holandesa, alemã ou italiana. Esboça-se uma tipologia, individualizando períodos, das diversificadas formas de expressão. No balanço global que se desenha, a propaganda rcvolucionária, apesar de sua vivacidade, está longe de ter o domínio do terreno. São conhecidas principalmente as séries de caricaturas que, de 1792 no Diretório, com uma interessantíssima seqüência do ano II (quando David e alguns outros foram convidados a colocar seu talento a serviço da causa) foram consagradas à denúncia, ou à irrisão dos déspotas. Desde a passada imperial de Catarina, a Grande, de Moscou a Istambul até o Regimento dos Royal-Cruches recrutado pelo rei Georges III, a estampa revolucionária zombou a valer. Mas ainda são produçōes mais para o mercado interior que para a difusão no Exterior. Alternâncias se desenham nos primeiros anos da Revoluçāo, uma iconografia simpática à Revoluçāo, que reproduz seus emblemas e símbolos (a Liberdade, a árvore da Liberdade); existe no Império e pode ser encontrada nos almanaques. Breve seqüência que a censura dos soberanos rapidamente interrompe. Na Itália de 1796, uma onda de iconografias revolucionárias irrompe, de Milão a Veneza, glosando soore o terror dos aristocratas, a alegria de Arlequim dançando ao pé da árvore da Liberdade, as desventuras do velho leâo de São Marco... Mas o retomo strá brutal, de 1798 a 1799, a caricatura italiana, muitas vezes sob incitação direta dos Habsbourg, produzira em Bassano ou em outros lugares toda uma torrente de imagens violentamente contra-revolucionárias, associando em seu exorcismo os comissários do Diretório, os jacobinos locais, e as frágeis repúblicas irmãs, postas à morte no dia seguinte de seu nascimento. Essa produçāo, relativamente tardia, só faz integrarse a um fluxo mais precoce cujos centros foram, desde 1790, a Inglaterra, a Holanda e a Alemanha, cada qual à sua maneira. Os mestres da caricatura inglesa - Gillray, Rowlandson, Cruickshank - logo serviram-se de sua verve para evocar fantástica e ferozmente as torpezas francesas, iniciando um fluxo que se prosseguirá sob o Império. Se essa produção é razoavelmente conhecida, não deve fazer esquecer a outra corrente, hagiográfica, que focaliza as desventuras do rei. Um estilo sério encontrado também na Holanda, desde 1792, na ilustração dos massacres de setembro, assim como na Alemanha em tomo do tema da morte do rei...

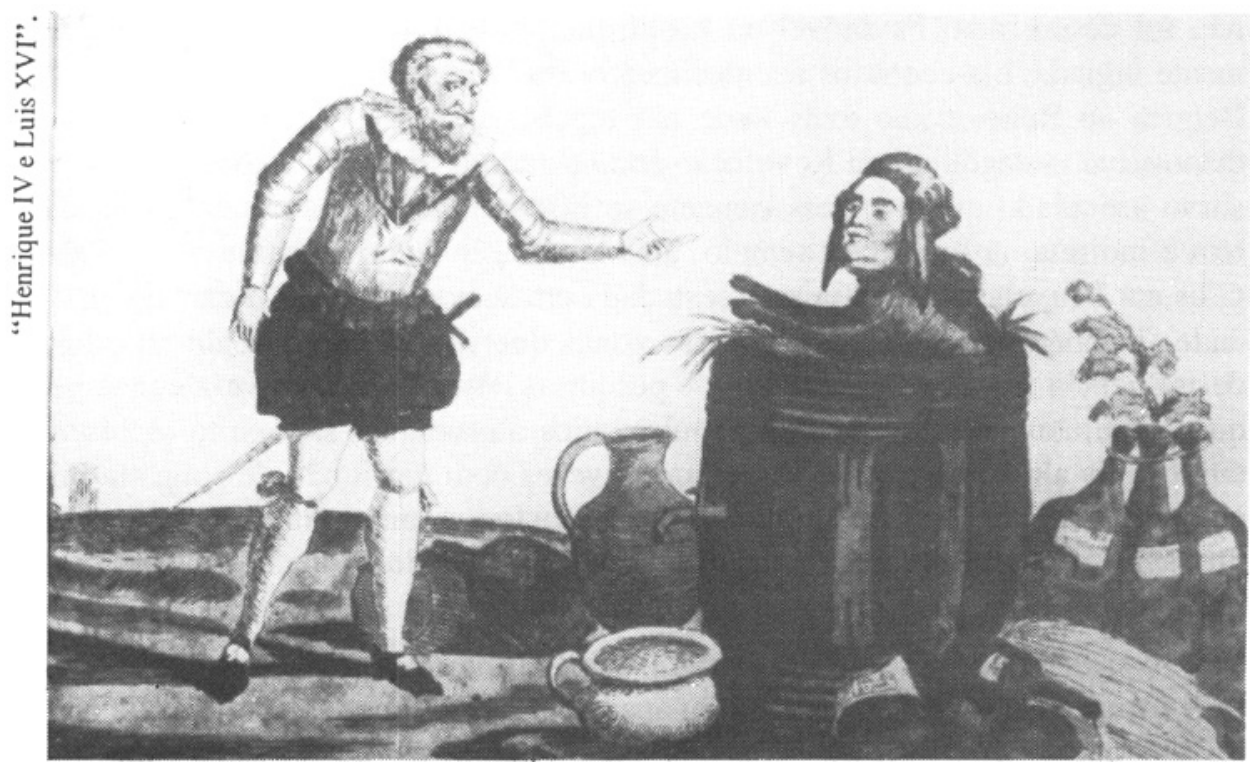


Canteiro aberto, donde a atenção a ele aqui dedicada. Em função disso, há todo um estudo a ser aprofundado sobre um dos outros suportes da propaganda, desta vez, essencialmente revolucionária: é o da festa, exportado de seu quadro francês aos países atingidos diretamente pela expansão revolucionária. De Mayence a Trêves, de Mons a Bruxelas, em 1792, a Amsterdã, em 1794, depois Milão, Veneza, Roma e Nápoles, de 1796 a 1\%198, a testa revolucionária transplantada de seu lugar de origem torna-se a manifestaçâo simbólica e proclamatória da mudança do mundo. Isso nem sempre acontece sem dificuldades, que se devem, em parte, como é o caso da Itália, à defasagem com relação às cerimônias francesas a que se refere. Mas em todos os lugares, cidades e às vezes campos, a plantação da árvore da Liberdade - da Renânia do Travestevère passando pela Suíça - representou o gesto mais altamente simbólico que a gravura celebra e que a lembrança pode guardar.

Através desses diferentes suportes, como através da ação desses homens, grupos ou individualidades, sente-se o quanto é difícil evocar em termos simples o eco imediato ou a quente da Revolução Francesa: de passar da questão voluntariamente ingênua com que abrimos esta seqüência: $O$ que souberam dela? à questão reformulada: $O$ que perceberam dela?, ou ainda melhor, Que fizeram dela?

De acordo com os lugares, esse eco pode reduzir-se a algumas imagens, alguns clichês, ou alguns símbolos, ou aumentar nas dimensões de uma interrogação radical, de um novo questionamento de toda a herança das Luzes e da Europa dos príncipes esclarecidos, comparados à solidez do acontecimento. Imenso canteiro que nós não tentaremos prospectar. A Revolução aparece nele com toda a ambigüidade de seu impacto ideológico, portadora de todas as ideologias da liberação dos indivíduos e dos povos, através do despertar das naçōes; está também na origem de toda reflexão contra-revolucionária, que de Burke a Maistre, Bonald ou Haller, vai fundar as bases de uma outra corrente de pensamento dominante do século XIX, muito além da seqüência precisa da Restauração triunfante. Porque esses pensadores e teóricos, que vieram depois de Burke e precisaram passar pela história para fundar em direito a legitimidade de sua meditação sobre a continuidade da cadeia do tempo e a ordern que regia as sociedades humanas, vão muito além do simples reflexo dominado pelo medo dos grupos dominantes diante do contágio revolucionário.

Numa passagem que ficou célebre, Georges Lefebvre definia a mentalidade revolucionária como dividida entre duas pulsões: a esperança e o medo. No campo do imaginário coletivo, cremos não ser imprudente extrapolar ao conjunto da Europa, depois ao mundo, para dizer que a Revolução lega aos povos ao mesmo tempo a esperança e o medo, simpatia e fascinação, ao mesmo tempo que rejeição, distintamente formulados.

É possível, depois de Jacques Godechot, modular a análise dessas atitu-

Numa passagem que ficou célebre, Georges Lefebvre definia a mentalidade revolucionária como dividida entre duas pulsōes: a esperança e o medo. des, ao mesmo tempo no espaço e no tempo. No tempo, num corte amplo, distinguir-se-á uma primeira fase até 92 (formação da coalizão) ou mesmo 93 (à morte do rei, e o Terror) onde a adesão de uma parte das elites inscreve-se numa política de contemporização das potências monárquicas - da fase de 1793-1799 - onde a propaganda direta, por via de expansão de guerra fora da França, se choca com a contra-ofensiva não apenas militar, mas ideológica, de uma Europa monárquica coligada. Enfim, uma última seqüência seria realmen- 
te, de 1800 a 1815 , aquela em que a conquista imperial difunde através da Europa não apenas a mensagem revolucionária em sua pureza, mas o que lhe absorveu o regime. A esta modulação no tempo, correspondem no espaço diversos modelos dé propagação ou de recepção do eco da Revolução: bem diferente dos novos territórios que entraram diretamente no espaço francês, aos territórios sob influência direta dos termos da conquista, aos que conheceram apenas uma imagem indireta, longínqua e peneirada pelos filtros da censura. Sem falar do quarto círculo dos que, demasiadamente distantes ou ainda diferentes, se situam fora do campo das conseqüências do acontecimento. Esses descobrirão a Revolução apenas de maneira diferida.

\section{O Eco Diferido: ou a Revolução após a Revolução}

Trata-se de dar contas de um segundo efeito do eco - mesmo sendo evidente que de um a outro há continuidade; mas é preciso doravante considerar, no campo histórico, as transformaçōes de uma imagem e de toda uma série de idéias - forças que constituem propriamente a herança da Revolução.

Tal interrogação não saberia evitar uma pergunta prévia - com o risco de reencontrá-la, in fine - sobre as razōes do impacto excepcional da Revolução de 1789. A problemática comparatista proposta pelos defensores das "Revoluções Atlânticas" tem ao menos isto de bom; substituindo os acontecimentos anteriores, desde 1770 e dos que se seguiram até 1820, faz com que apareça não somente a importância do novo impulso que gera por contágio direto, ou por seu exemplo, mas também a importância incomparável do choque que provocou.

A imponência do acontecimento que teve lugar na França, e seu poder de expansão direta também, explicam que ela tenha, de certo modo, ofuscado os outros movimentos contemporâneos ou antecedentes. Apesar das proclamaçōes e experiências de que foi suporte no campo político e institucional, a Revoluçăo Americana viu-se confinada entre as idéias recebidas nos limites de uma conquista de independência nacional. $O$ que não impede, como fazemos, de estudar sua influência tanto sobre a Revolução Francesa, como sobre a dos Países Baixos ou sobre o pensamento europeu no horizonte de 1800. Mas é realmente a referência francesa que por mais de um século, pelo menos, constituiuse em modelo. Que tenha havido influência direta e assimilação, como numa parte da Itália, ou encaminhamento mais complexo que passa pela rejeição da conquista revolucionária e mais ainda, imperial, para encontrar no fogo da tomada de consciência nacional das guerras patrióticas, uma certa herança da $\mathbf{R e}$ volução, a referência francesa serviu de matriz às revoluçōes nacionais e liberais do século XIX até 1917; referência obrigada, de que a Marselhesa, primeiro hino revolucionário de vocação mundial antes da Internacional, era o suporte.

Pode-se surpreender com esta fortuna cujos testemunhos no pensamento político, na literatura, nas expressões artísticas e no imaginário coletivo fornecem as múltiplas provas. A bem dizer, mede-se aí a plasticidade de uma herança susceptível de reutilização, alteraçōes, certeza de uma sobrevivência duradoura.

Como se forma um modelo? Como anteriormente, sendo mais em termos de programa que de balanço acabado que se pode esboçar com grandes traços

\author{
Apesar das \\ proclamaçöes e \\ experiências de que foi \\ suporte no campo \\ polifico e \\ institucional, a \\ Revoluçäo Americana \\ viu-se confinada entre \\ as idéias recebidas nos \\ limites de uma \\ conquista de \\ independência \\ nacional.
}




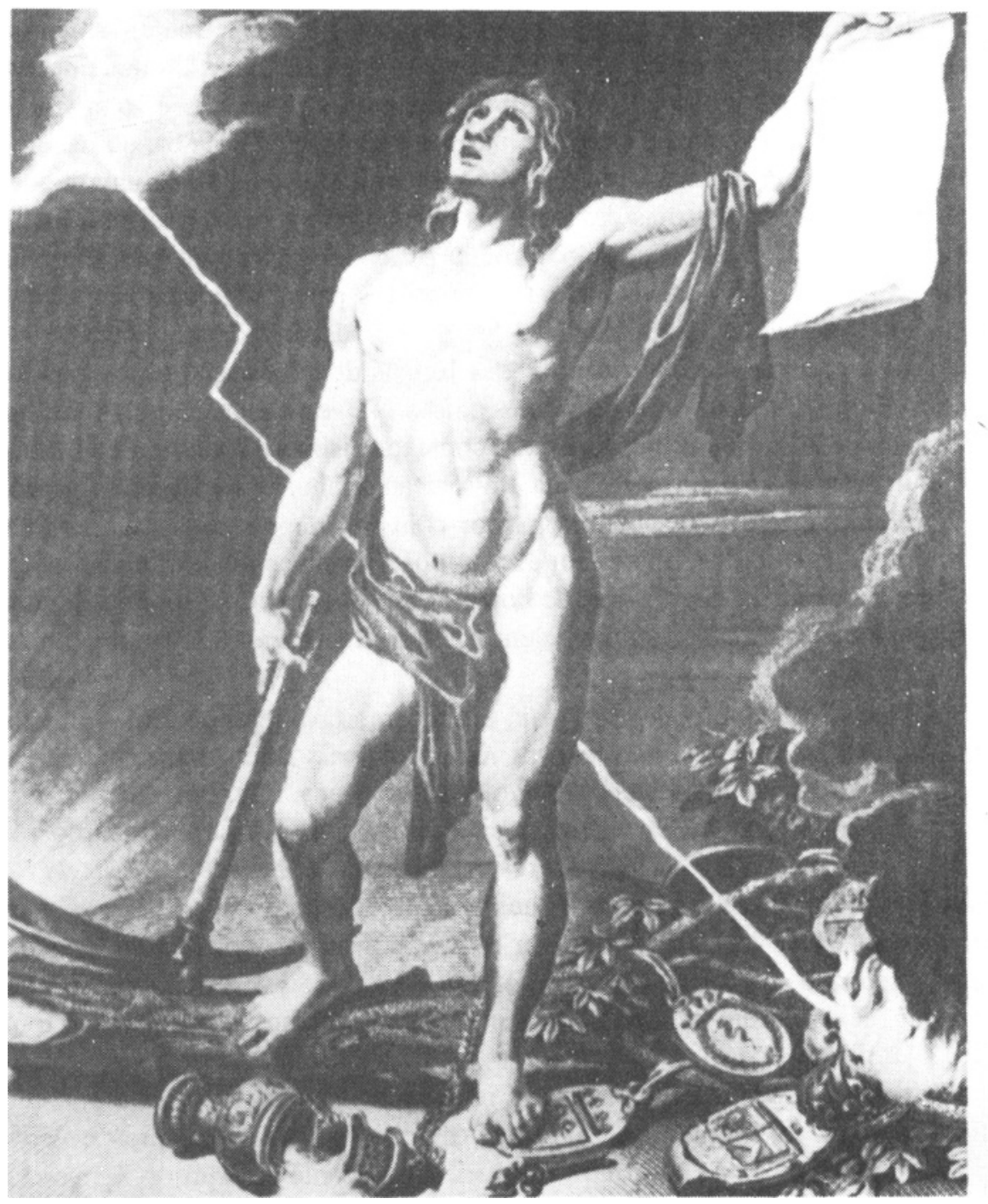

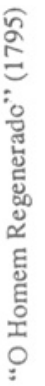

este percurso. Por que vias, a partir de 1815, entrou a Revoluçāo Francesa na memória coletiva e no patrimônio comum da humanidade?

Tentou-se começar pela história, suporte natural da memória. Sem voltar pelo percurso historiográfico pelo qual abrimos esta exposição, é provável que o estudo comparado da maneira como a história da Revolução e de sua influência penetrou nos diferentes países forneça um fio condutor bastante sugestivo. As grandes produções dos historiadores franceses do século XIX, da primeira geração de Thiers e Mignet, à dos anos 1840 a 1860, onde Michelet, Lamartine, Quinet, magnificam o tema, até as histórias socialistas de Louis Blanc, Esquiros, Buchez (e chegando a Jaurès!), depois a virada de uma historiografia positivista que nem por isso é mais serena, a escola francesa dá o tom: e seria um primeiro terreno considerar, a partir de suas traduçōes, a fortuna literária destes ecos, através do século XIX da Revolução Francesa. Mas as escolas européias não ficaram desatentas: desde 1937, Carlyle já propõe sua "History of the French Revolution", um dos primeiros grandes monumentos desse corpus historiográfico, e na Alemanha, como vimos, von Sybel ataca o problema nos anos 50, numa perspectiva européia. Mais ainda que a essas obras-marcos atamo-nos 
hoje legitimamente - as comunicaçōes apresentadas sãò testemunhas disso - a uma difusão mais modesta e talivez menos espetacular, mas de qualquer forma menos conhecida, no quadro dos diferentes países. Recentes estudos tratavam sobre o eco da Revoluçāo Francesa na Romênia (AHRF, 1986), ou na Hungria (Colóquio Franco-Húngaro, Paris 1986), evocando as etapas de uma descoberta, do século XIX aos dias de hoje. Eis um canteiro sobre o qual se trabalha da Europa à América e ao Extremo Oriente: pode-se esperar que as confrontaçōes que acontecerão durante os encontros previstos para 1989 em torno da "Imagem da Revolução" permitam fazê-lo avançar decisivamente, introduzindo a uma visão comparada dos ritmos e das formas de penetração das idéias-forças da Revolução Francesa nos diferentes países. Talvez ela descubra zonas, ou sequiências de silêncio, explicáveis pelo contexto histórico (penso em tal pesquisa em curso sobre a historiografia da Revolução Francesa na Espanha no século $\mathrm{XX}$ ). Continuando com a interrogação, convém; depois de se ter perguntado como a história da Revolução foi escrita nos diferentes países, tentar saber como ela foi ensinada até os dias de hoje: tal estudo, em curso sobre a Revolução Francesa nos manuais escolares alemães (Sproll), inscreve-se no quadro dessa curiosidade.

Para dizer a verdade, por mais estimulante que seja, o recurso dos historiadores nāo é o único, talvez nem mesmo o mais direto para apreciar a via póstuma dos temas tratados pela Revoluçāo Francesa. Digamos que a uma certa data (podendo talvez uma charneira simbolia ser proposta na virada do século XIX e do século XX), quando Jaurès escreve sua História Socialista da Revolução, um escrito de história mais universitário, ou erudito, substitui as grandes profissões de fé histórica da época romântica, ou pós-romântica. $O$ que não quer dizer que o testemunho doravante dado seja mais objetivo ou subtraído às contingências de um momento. Mas essa virada afiança uma distância tomada do objeto Revolução.

Também estimulante, o tema da imagem da Revolução Francesa, tal como foi veiculada na literatura e nas artes, oferece um quadro de prospecçāo amplamente aberto. Foi objeto na França de um recente colóquio (Clermont Ferrand, 1986) sobre $A$ Legenda da Revoluçâo: apesar do quadro de reflexão não se ter limitado à França, resta ainda abri-lo amplamente aos diferentes ecos europeus. Num mundo germânico, onde as grandes testemunhas da virada do século (Kant, Fichte, Goethe, Schiller) haviam dedicado uma apaixonada atenção à Revolução Francesa, George Büchner lança, já em 1834, sua Morte de Danton, ao mesmo tempo reflexão e testemunho da fascinação que exerce sobre os jovens liberais dos anos 30, o exemplo da Grande Revolução. Da expressão literária à tradução gráfica, a história da Revolução fornece ao século XIX toda uma série de temas, de personagens por vezes pretextos para empossar símbolos ou fantasmas (pensemos na série das gravuras de Eduard Munch sobre o tema "a morte de Marat"), dos suportes tradicionais da comunicaçăo às novas mídias, o encadeamento faz-se naturalmente, como do teatro ao cinema. Foi inspirando-se numa peça polonesa da década de 1920, da qual módificou o espírito, que Wadja roda na década de 1980 seu filme Danton.

A literatura e o discurso propriamente político continuaram sendo muito naturalmente o lugar onde se inscreve a referência à Revolução Francesa, permanecendo até $o$ início do século $\mathrm{XX}$ a referência maior a uma modificação violenta da ordem social e institucional, como o lugar fundador de toda uma
... convém, depois de se ter perguntado como a historia da Revoluçáo fol escrita nos diferentes países, tentar saber como ela fol ensinada até os dias de hoje.




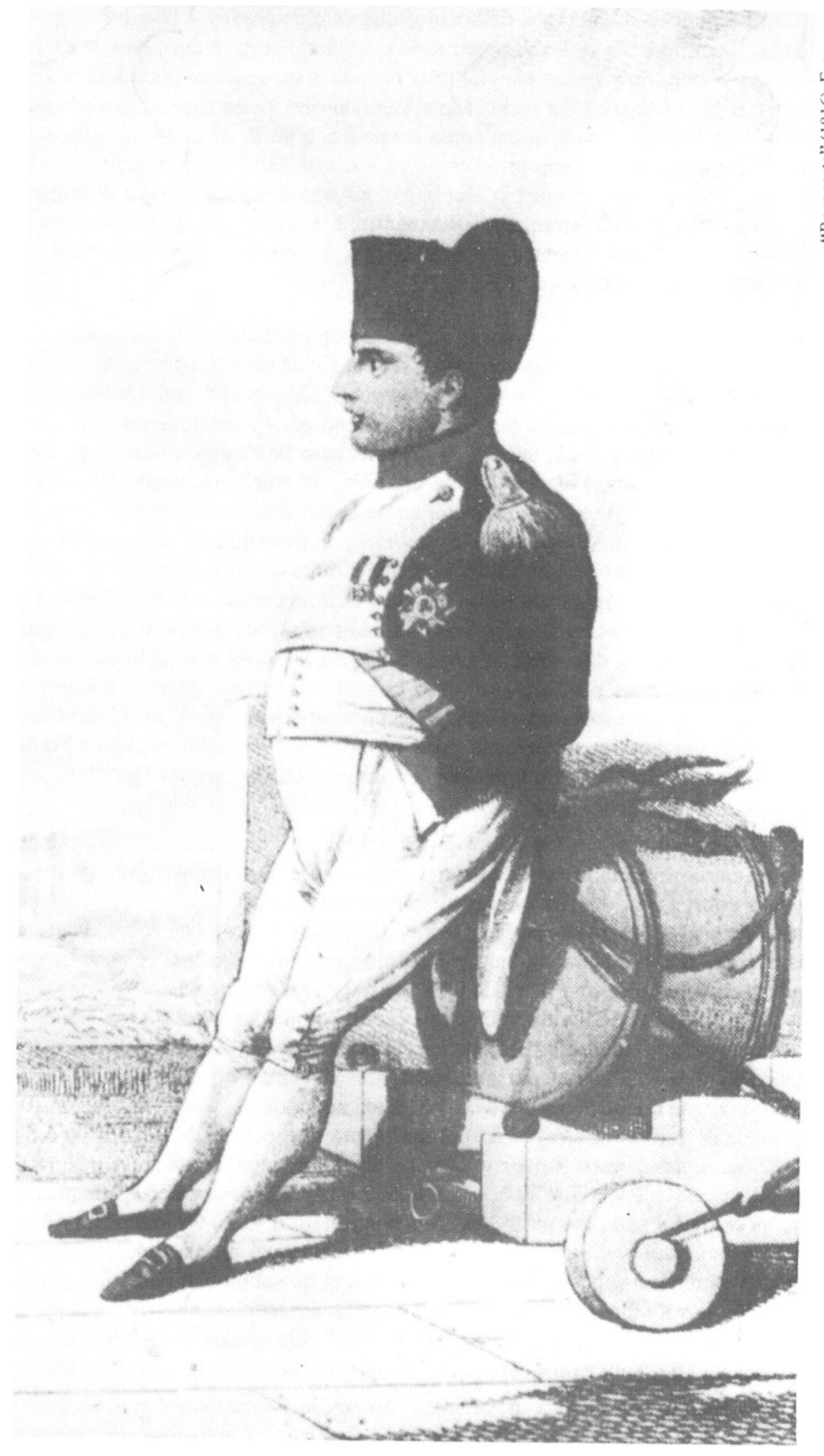

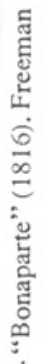


filosofia política. Lembrança da herança dos valores-chaves - liberdade, igualdade, fraternidade - reflexão sobre as vias da passagem de um estado social a um outro, pela riqueza das experiências históricas da qual era portadora, a Revolução Francesa pôde ser reclamada sucessivamente pelos movimentos liberais do século XIX nacionais, assim como conheceu, a partir de 1848, uma espécie de apropriação pelas correntes socialistas, e o movimento operário, integrando em seu patrimônio a referência a essa experiência coletiva. No que definimos como plasticidade da herança revolucionária, é evidente que não foram considerados os mesmos aspectos da herança, ou os mesmos heróis, de 1789 ou 1793, Mirabeau ou Robespierre.

O canteiro continua imenso, do estudo da referência revolucionária nos discursos como nas doutrinas políticas, de ontem até hoje. Monografias são dedicadas a ele (prova disso são os estudos publicados recentemente sobre a Revolução Francesa no pensamento de Marx, tanto por F. Furet, como após o colóquio realizado em Paris em 1985, pelo Instituto de Pesquisa Marxista). Não sendo possível tratar desse problema em toda sua amplitude, somos levados a tomar como exemplo a riqueza histórica de certas palavras-chaves ou referências históricas: como o conceito de jacobino e de jacobinismo, seguramente um dos temas mais sensíveis na medida em que suscita o questionamento de toda a especificidade do organismo revolucionário experimentado pela Revolução. De Michelet, que vê nela um instrumento de inquisição e de ditadura, assim como Quinet, em termos diferentes, a Louis Blanc;ou a Jaurès, que justifica sua necessidade, o debate percorre a reflexão francesa até os dias de hoje. Encontrou seu eco no pensamento internacional, e pode-se seguir, de Marx a Gramsci, passando por Lenine, a evolução do conceito de jacobino (Marx, fevereiro de 1848: "existem na história analogias surpreendentes. O jacobino de 1793 tornou-se o comunista de hoje ").

Atendo-nos a este rápido inventário das formas elaboradas da reflexão ou da memória revolucionária na história, na literatura ou no pensamento político, temos consciência de abordar apenas um aspecto do problema - certamente o mais simples -, deixando de lado outras dimensões daquilo que se pode definir como eco da Revolução, assim como aquilo que se poderia definir como a memória da Revolução, no nível de uma transmissão direta ou reavivada, nos países que tiveram oportunidade de conhecer-lhe diretamente os efeitos - anexados a um tempo, marcados profundamente pelo episódio. Através de uma historiografia clássica, voluntariamente contra-revolucionária, pode-se ter o sentimento de que o legado negativo ou a legenda negra da desordem revolucionária geralmente prevalece através do encadeamento das guerras da Revolução e do Império, indissociadas. Talvez convenha distinguir, segundo as áreas geograficas e sua experiência histórica, como também segundo as condiçōes em que essa memória foi mantida, ou mesmo formada, ulteriormente. Os mineiros de Borinage, que até os últimos anos escalavam anualmente, no dia 6 de novembro, as alturas de Jemmapes para ali saudar o nascer do sol ouvindo a leitura da declaração dos Direitos do Homem, cumpriam um cerimonial antigo, ou mais provavelmente, nascido em algum momento da segunda metade do século XIX, no cruzamento de sentimentos patrióticos, democráticos e do movimento social.

Toda uma história da memória da Revolução Francesa está para ser escrita, estando bem-entendido que a memória se fabrica e se elabora no decorrer do
Toda uma hist6ria da memória da Revolução Francesa está para ser escrita, estando bem-entendido que a memoria se fabrica e se elabora no decorrer do tempo. 
tempo. No eco da Revolução, convém seguir os tempos fortes e os tempos fracos: tempos fortes das pulsões revolucionárias, de 1820 , de 1830 e 1848, sobretudo quando o referente histórico foi invocado num contexto revolucionário. E a Revoluçāo soviética de 1917, que inaugurava uma estátua de Danton, como dava a um monumento de guerra o nome de Marat, invocou, ela também, esta herança.

Desta memória moldada, nutrida das experiências próprias de cada país, gostaríamos de analisar os elementos, os pontos de referência, ou as passagens obrigatórias. Tal como se inscreve no imaginário coletivo, é necessariamente simplificadora, remetendo a idéias-força simples - a tríade Liberdade-Igualdade-Fraternidade - a alguns acontecimentos de massá - o 14 de Julho - a símbolos - a Marselhesa e a algumas figuras escolhidas. As aventuras da Marselhesa, a história de suas tradiçōes, de suas adaptações, como de sua difusão através do mundo, e da função que teve nas grandes crises revolucionárias são bastante conhecidas por terem atraído a atenção de inúmeros eruditos. Mas podemos também conduzir um levantamento sobre a riqueza póstuma, através dos tempos e lugares da Europa Central à América Latina, dos heróis-símbolos da Revolução - Danton, Robespierre - e alguns outros.

Quem fala em história da memória, fala também em história do esquecimento. Durante muito tempo-modelo ou referência única, pode-se pensar que o eco da Revolução Francesa sofreu a dupla erosão do tempo e da banalização parcial de uma parte dos valores de que era portadora, como de uma continuidade na consciência coletiva adquirida pelas revoluçōes do século $\mathrm{XX}$. Tal esquema, indiscutivel em alguns aspectos, merece ser matizado. Existem fenômenos de redescoberta, ou de reativação sobre bases diferentes de um legado histórico, cuja referência no caso francês fornece vários exemplos: assim como no movimento operário francês, a reabilitaçāo entre 1934 e 1944 da Frente Popular à Resistência, através da Marselhesa e das três cores, de uma Revolução burguesa, durante um tempo depreciada. Também assistimos, às vésperas do Bicentenário, à volta ao jogo de antigas fraturas, por onde, em termos por vezes imprevistos, manifesta-se a vitalidade de uma lembrança que se poderia crer enfraquecida.

Muito paradoxalmente, no momento em que uma imagem que se podia crer soilidamente estabelecida da Revolução emancipadora e mãe das Liberdades encontra-se contestada pelo despertar de um discurso vindo da tradição contra-revolucionária, que faz dela o lugar da violência cega e a encarnação do mal absoluto, pode-se ter a impressão que a imagem internacional, tal como prevalece no Exterior, continua geralmente mais fiel a uma apreciação positiva, a mesma formada quase há dois séculos de trabalho da memória coletiva. Seria imprudente, no campo da história imediata, arriscar-se, a partir dessa impressão do instante, a conclusóes excessivamente apressadas.

Ao menos podemos constatar, através da vivacidade dos debates atuais, $o$ poder de uma marca duradoura na longa duração dos dois séculos que nos separam da Revolução. Prova, talvez, de que a idéia-força não esteja absolutamente morta, nem o eco totalmente ensurdecido.

Michel Vovelle e diretor do Instituto de Historia da Revolução Francesa (França) e participará do colóquio 1789 - Sombras e Luzes em setembro (1989) no IEA. 